\title{
INNY W POLSCE. KOMUNIKACJA INTERKULTUROWA W PAŃSTWIE NARODOWYM
}

\author{
ELIZA GRZELAK ${ }^{1}$ \\ (Uniwersytet im. Adama Mickiewicza w Poznaniu)
}

\begin{abstract}
Słowa kluczowe: komunikacja interkulturowa, homo sovieticus, społeczeństwo dominujące, mniejszości etniczne, mniejszości narodowe, asymilacja, integracja, wielokulturowość
\end{abstract}

Key words: intercultural communication, homo sovieticus, dominant society, ethnic minorities, national minorities, assimilation, integration, multiculturalism

\begin{abstract}
Abstrakt: Eliza Grzelak. INNY W POLSCE. KOMUNIKACJA INTERKULTUROWA W PAŃSTWIE NARODOWYM. „PORÓWNANIA” 16 (2015). T. XVI. S. 147-163. ISSN 1733-165X. Autorka analizuje problem komunikacji między społeczeństwem dominującym a mniejszościami narodowymi i etnicznymi. Zwraca uwagę na kategorię swój / obcy regulującą relacje społeczne, ich zakorzenienie kulturowe i genezę polityczną . Ponadto definiuję na potrzeby wystąpienia, w oparciu o własne badania, pojęcie 'państwo narodowe'. Kulturowe rozumienie inności omawia, przywołując cztery postawy: odrzucenie, nietolerancję, tolerancję i akceptację. Identyfikuje także bariery, utrudniające fortunną komunikację na granicy kultur, mające swą genezę w zmieniającym się układzie geopolitycznym. Stosunek do inności w Polsce ilustruje werbalnymi i niewerbalnymi zachowaniami komunikacyjnymi, poszukuje ich przyczyn $w$ systemach prawnym i edukacyjnym, które są dziedzictwem PRL-u. W swoich rozważaniach bierze pod uwagę czynniki, wpływające na kształtowanie relacji interkulturowych w Polsce po 1989 roku:

- totalitaryzm utrwalony w pamięci społecznej,

- zniesienia cenzury,

- dynamikę procesów globalizacyjnych,

- determinizm technologiczny relacji interpersonalnych i interkulturowych,

- przeobrażenia aksjologiczne.
\end{abstract}

Na zakończenie, na podstawie wyników badań, opisuje tendencje w zakresie omawianych relacji.

\footnotetext{
${ }^{1}$ Correspondence Address: kontakt@elizagrzelak.pl
} 


\begin{abstract}
Eliza Grzelak, THE OTHER IN POLAND. INTERCULTURAL COMMUNICATION IN THE NATIONAL STATE. "PORÓWNANIA" 16 (2015). Vol. XVI. P. 147-163. ISSN 1733-165X. The author analyses a problem of communication between a dominant society and national and ethnic minorities. She focuses on a category of one's/ other that regulates social relations, their cultural roots and political origin. Additionally, for the purposes of the speech, the author defines 'a national state' term based on her own research in the field. Cultural understanding of otherness is explained based on four attitudes: rejection, intolerance, tolerance and acceptance. Barriers that hamper a fortunate communication on the edge of cultures and origin from a changing geopolitical system are identified. The author illustrates the attitude towards otherness with verbal and nonverbal communicational behaviors, investigates their causes in legal and educational systems which are the heritage of Polish People's Republic times. She considers the following aspects that have shaped intercultural relations in Poland after 1989:

- totalitarianism imprinted in social memory of people,

- abolition of censorship,

- globalization processes dynamics,

- technological determinism of interpersonal and intercultural relations,

- axiological changes.
\end{abstract}

Finally, the author describes the tendencies of the above relations based on the results of research.

Przedmiotem niniejszych rozważań jest komunikacja interkulturowa w Polsce po 1989 roku, szczególnie wpływ pamięci posttotalitarnej na obecne relacje między społecznością dominującą a mniejszościami etnicznymi. Rozwiązania prawne i społeczne, obowiązujące na świecie, w sytuacji polskiej zostały zweryfikowane w procesie dochodzenia do demokracji. Rozwiązania prawne po 1989 roku, choć pozwoliły przejść od procesów asymilacyjnych do integracji wzmocnionej wielokulturowością i odejść od idei państwa narodowego (jednorodnego ideologicznie i kulturowo) w kierunku wielokulturowego, w niewielkim stopniu zmodyfikowały nieoficjalne postawy Polaków wobec Innego. W konsekwencji istotne okazało się zdefiniowanie przyczyn niefortunnych ciągle jeszcze relacji komunikacyjnych na granicy kultur w Polsce.

\title{
1. Homo postsovieticus - kontekst społeczny komunikacji interkulturowej w Polsce
}

Przełom ustrojowy, który dokonał się w1989 roku w Polsce, dowiódł Polakom, że zagospodarowywanie wolności może być równie trudne, jak jej odzyskiwanie. Nieograniczona swoboda użycia języka, kształtowania własnej tożsamości, for- 
mowania przekonań i wyznawania wiary w społeczeństwie, żyjącym dotychczas w ściśle wyznaczonych przez władzę granicach, okazały się dla Polaków wyzwaniem. Powoli uświadamiano sobie, że wolność to nie anarchia, że istnieją jej ograniczenia etyczne, konwencjonalne, które $\mathrm{w}$ demokratyczny państwie, w oparciu o istniejące prawo, każdy musi identyfikować samodzielnie. Najbardziej widoczną wolnością, wymagającą ograniczenia, była wolność słowa. Społeczeństwo polskie, po ponad stu latach zaborów, globalnej wojnie i pół wieku rządów totalitarnych nie znało autocenzury. Tabu językowe i konwencja etykietalna okazały się niewystarczającym ograniczeniem swobody werbalnej. Próba ujarzmienia anarchii słowa spotykała się z odpowiedziami: to narusza prawo do wolności słowa, mamy zagwarantowana wolność słowa, moge mówić co chcę, jest wolność stowa, ludzie maja prawo wiedzieć. Tak rozumiana wolność dotyczyła formy przekazu, zakresu przekazu i prawa do ujawnienia treści. Odpowiedzią na takie zachowania komunikacyjne była ustawa o języku polskim (Dziennik Ustaw 1999, nr 90, poz. 999), także rozwiązania prawne dotyczące ochrony danych osobowych (Dziennik Ustaw 1997 nr 133 poz. 88) i dóbr osobistych (Waglowski), stalkingu (Dziennik Ustaw 2011, nr 72, poz. 381), szerzenia nienawiści rasowej i etnicznej, w tym mowy nienawiści (Waglowski). Nie jest to jednak problem zamknięty, czego dowodzi walka o choćby częściowe zapanowanie nad wolnością komunikacji elektronicznej² ${ }^{2}$ Problemem pozostaje niski poziom przekazu dziennikarskiego ${ }^{3}$ i demokratyczny niedostatek ograniczeń w tym zakresie (Dziennik Ustaw 2013, nr 0, poz. 771).

Zaangażowanie Kościoła w odzyskiwanie wolności oraz jej budowanie po 1989 roku, wygenerowały problem neutralności światopoglądowej państwa. W mediach i parlamencie toczą się dyskusje na temat zakresu wolności wyznania. Prawnicy pracują nad definicją religii i wyznania, często także odpowiadają na zapytania o granice wolności wyznania i zgodność z prawem praktyk religijnych ${ }^{4}$. Ścierają się dwie postawy społeczne, dla jednych Polska ma być państwem, w którym równe prawa mają wszystkie wyznania, dla innych powinna być państwem publicznie pozbawionym oznak religijności.

Wymiana świąt narodowych $\mathrm{i}$ rozbudowanie kalendarza $\mathrm{w}$ tym zakresie, zmiana konstytucji, odtworzenie senatu, przejście od gospodarki socjalizmu realnego do wolnorynkowej, otwarcie granic, wstąpienie do Unii Europejskiej i NATO, nasilenie procesów globalizacyjnych, powszechna migracja młodych ludzi nie zneutralizowały świadomości posttotalitarnej Polaków. $2010 \mathrm{r}$.

${ }^{2}$ Np. odrzucona umowa międzynarodowa Anti-Counterfeiting Trade Agreement z 15 listopada

${ }^{3}$ Dominującą tendencją dziennikarskiego przekazu elektronicznego jest jego dynamicznie postępująca tabloidyzacja.

${ }^{4}$ Rozwiązania prawne służące ochronie uczuć religijnych, dotyczące nauczania religii, czy rozwiązania ekonomiczne ograniczające np. ubój rytualny są przedmiotem dyskusji społecznej, w której argumentem są często prawa wyznaniowe oraz neutralność światopoglądowa Polski. 
Starzeje się pokolenie, które czasy PRL-u wspomina jako czasy dzieciństwa i młodości, dlatego z radością odwiedza, powstające coraz liczniej, muzea PRL-u ${ }^{5}$. Pamięć ludzka posiada specyficzną cechę, przechowuje częściej chwile miłe, wzbudzające pozytywne emocje, dlatego Polacy pamiętają, że wtedy wszyscy byliśmy równie biedni, ale mieliśmy pracę, żyło się radośniej, zaczynają tęsknić do wspólnych obchodów 1. maja i 22. lipca. Najstarsi pamiętają, że był to czas, gdy ludzie się spotykali, nikt nie był samotny. Ta tęsknota, czasem nawet nieświadoma, za PRL-em nie jest warunkowana wyłącznie frustracją ekonomiczną. Wzrastające zainteresowanie młodych ludzi klasami mundurowymi postrzegane jest przez pedagogów i nauczycieli jako forma realizacji planów zawodowych (Kapica 2014). Jednak ankiety przeprowadzone wśród uczniów tych klas dowiodły, że tylko część z nich (34\%) zamierza w przyszłości pracować w policji lub wojsku, 22\% jeszcze nie ma sprecyzowanych planów zawodowych, pozostali nie podjęli żadnej decyzji. Około $70 \%$ procent, wypełniając ankiety, nie potrafiło wskazać, co ostatecznie zdecydowało o wyborze tej klasy ${ }^{6}$. Odpowiedź na to pytanie pojawiła się $\mathrm{w}$ informacjach uzyskanych $\mathrm{w}$ wywiadach indywidualnych. Młodzi ludzie uważają, że w zawodach mundurowych decyduje dowódca, wykonuje się rozkazy, są wyraźne procedury. Nastolatkowie urodzeni w wolnej Polsce, podświadomie poszukują ograniczeń, uciekają od możliwości dokonywania własnych wyborów. Taką postawę społeczną potwierdza długotrwała, silna więź ekonomiczna i emocjonalna młodych Polaków z rodzicami i opiekunami.

W przekazach medialnych coraz częściej pojawia się w różnych kontekstach zarzut: brak wyraźnych procedur, należy wypracować standardy, procedury, wyraźne zasady. Dotyczy to nie tylko działania szpitali, funkcjonowania służb w sytuacjach specjalnych, także relacji codziennych i zawodowych.

Ograniczone zadowolenie z demokracji i wolności potwierdza niska frekwencja w wyborach, obarczanie polityków winą za każde niepowodzenie, przekonanie o winie państwa, przejawiające się modnym ostatnio użyciem językowym: państwo się nie sprawdziło. Państwo to byt, który zwalnia Polaków z odpowiedzialności osobistej za własne decyzje i ze współodpowiedzialności za współobywateli. Wielu Polaków oczekuje odgórnych decyzji, które pomogą im podejmować własne. Rzadko reagują oni na niedoskonałości życia społecznego, jeszcze rzadziej podejmują inicjatywy społeczne, a te które inni podejmują, traktują z dużą podejrzliwością.

Przedstawiona powyżej analiza zachowań komunikacyjnych Polaków po 1989 roku, znajduje swoje potwierdzenie w nowym rozumieniu pojęcia homo sovieticus

\footnotetext{
${ }^{5}$ Obok muzeów powstają bary, restauracje, kluby utrzymane w klimacie PRL-u.

${ }^{6}$ Badaniami objęto 300 uczniów klas mundurowych w Wielkopolsce. Badania prowadzono w roku szkolnym 2013/2014.
} 
zaproponowanym przez ks. Józefa Tischnera (Tischner 1992, 1993) i Jerzego Turowicza (Turowicz). Tischner zwraca uwagę na powszechną próbę ucieczki od wolności, którą wcześniej opisał Erich Fromm (Fromm). Według Tischnera Polacy po wyzwoleniu z jednej niewoli szukają nowej. Turowicz natomiast opisuje specyficzne ubezwłasnowolnienie współczesnego homo sovieticus, który oczekuje, że wszystkie jego problemy rozwiąże państwo, władza lub na niższym szczeblu szef. Homo sovieticus Turowicza nie potrafi być krytyczny, nie podejmuje inicjatyw, nie jest kreatywny.

Nie są to jednak jedyne cechy identyfikujące postawy posttotalitarne wielu współczesnych Polaków. W zachowaniach interpersonalnych ujawniają się cechy wcześniejszego homo sovieticus utrwalone w pamięci społecznej:

- podporządkowanie grupie,

- uciekanie od odpowiedzialności,

- koniunkturalizm i oportunizm,

- agresywność wobec słabszych i uniżoność wobec silniejszych,

- brak samodzielnego myślenia oraz działania,

- oczekiwanie, że „ktoś coś załatwi” za niego,

- zniewolenie intelektualnie przez tych, którym się podporządkował (Wdowiak).

Wyniki badań nad współczesną komunikacją interkulturową w Polsce i jej determinizmem technologicznym ${ }^{7}$ potwierdzają, że współczesny homo sovieticus przyjmuje równolegle skrajnie odmienne postawy:

- próbie ucieczki od wolności towarzyszy często równie destrukcyjne, bezrefleksyjne zanurzenie się w wolności, graniczące z anarchią, szczególnie w zakresie wolności słowa.

- zachowaniom i oczekiwaniom globalnym towarzyszą zachowania umacniające tożsamość kulturową, budowaną na polskim mesjanizmie,

- niskiemu poczuciu własnej godności towarzyszy oczekiwanie od innych specjalnego traktowania Polski i Polaków, opartego na uznaniu i szacunku.

Powyższe analizy pokazują, że relacje społeczne między Polakami warunkowane są doświadczeniem totalitarnym. Dotyczy to także komunikacji między grupą dominującą a grupami mniejszościowymi, będącej podstawowym przedmiotem niniejszych rozważań, dlatego, opisując postrzeganie innego przez Polaków, należy uwzględnić uwarunkowania posttotalitarne uczestników komunikacji interpersonalnej i ich pamięć społeczną dotyczącą czasów PRL, gdyż obecne zachowania społeczne są efektem historycznego rozwoju relacji interkulturowych w Polsce po $1945 \mathrm{r}$.

7 Zob. (Grzelak, Grzelak-Piaskowska), (E. Grzelakowa, M. Rzeszutek), (Grzelak 2010), (Grzelak 2011). 


\section{Asymilacja - relacje interkulturowe w Polsce po 1945 roku}

Nowy system narzucony Polsce po 1945 roku zrównywał prawa obywateli niezależnie od ich narodowości. Idea „internacjonalizmu komunistycznego” (Rozental, Judin 246-248) stanowiła gwarancję praw mniejszości narodowych. Jednak żywa pamięć prześladowań wojennych i rozliczenia powojenne - przesiedlenia Niemców, akcja Wisła oraz migracje ludności na obszary dotąd zajmowane przez autochtonów, szczególnie na Mazury i Ziemie Odzyskane, rodziły konflikty na tle etnicznym. Według Konstytucji z 1952 r. suwerenem, do którego należy władza w PRL był lud pracujący miast i wsi. Zwierzchnictwo ludu/narodu realizowane było przez przedstawicieli. Konstytucja ta przyznawała wszystkim obywatelom te same prawa i obowiązki. Uznawała, że narodowość obywateli jest ich prywatną sprawą, dawała jednak prawo do zachowania i pielęgnowania swojej tożsamości. W praktyce jednak władze Polski dążyły do asymilacji mniejszości narodowych. Cechą polityki narodowościowej rządów komunistycznych było przekonanie, że mniejszości kulturowe, narodowe, etniczne, językowe są zjawiskiem negatywnym.

Socjolodzy i historycy zwracają uwagę na proces asymilacyjny jako rozwiązanie prawno-społeczne, wzmacniające więzi wewnątrzwspólnotowe (Funkenstein). $\mathrm{W}$ ramach procesów asymilacyjnych mniejszości etniczne, upodobniając się do dominującej populacji, przejmują między innymi jej system aksjologiczny, zwyczaje, język i w ten sposób stają się pełnoprawnymi obywatelami danego kraju. Polityka asymilacyjna zakłada minimalizowanie różnic pomiędzy członkami mniejszości etnicznych a społeczeństwem dominującym. Powinno to, według twórców tej teorii, zapobiegać konfliktom o podłożu etnicznym. Proces ten ma z reguły charakter jednostronnej adaptacji i absorpcji. Głęboka, komplementarna asymilacja społeczna zakłada wchłonięcie jednostki lub grupy przez grupę dominującą. W przypadku mniejszości etnicznych jest to przyjęcie cech kulturowych dominującej grupy narodowej. Asymilacja obejmuje całokształt procesów psychicznych i społecznych, którym podlegają jednostki, odłączające się od swojej grupy i przystosowujące się do życia w grupie odmiennej kulturowo.

Asymilacja tak pojmowana to nie proces wzajemnego przenikania się i łączenia, w wyniku którego jednostki oraz grupy poznają wspomnienia, uczucia, oraz postawy innych osób i grup, tworząc w ten sposób wspólne doświadczenie kulturowe, lecz proces zastępowania pamięci społecznej i kulturowej grupy słabszej cechami tożsamościowymi grupy silniejszej.

Podstawą działań asymilacyjnych jest wymóg prawny i pragmatyczny opanowania przez mniejszości narodowe i etniczne języka grupy dominującej. Konieczność posługiwania się nim także w sytuacjach nieformalnych, prowadzi do przejęcia wraz z nim sposobu myślenia, systemu aksjologicznego, sposobów kategoryzacji, rozumienia pojęć zgodnego z doświadczeniem dominatora. Konwersja językowa 
osłabia własną tożsamość, niszczy korzenie kulturowe (Kłoskowska). Na tożsamościową funkcję języka zwracali uwagę Johann Gottfried Herder i Wilhelm Humboldt - twórcy jednej z teorii poznania (Schaff). Herder zakładał, że skoro człowiek myśli za pomocą słów, to właśnie język wyznacza granice jego poznania. Zawarta w języku wiedza, wynikająca $\mathrm{z}$ doświadczenia pokoleń, kształtuje tożsamość użytkownika języka. Język, wpływając na myśl, kształtuje obraz rzeczywistości zgodny z utrwalonym w nim poglądem.

We wspólnotach totalitarnych upowszechniała się zideologizowana nowomowa. Społeczeństwo w państwie totalitarnym było równoprawne/jednolite, akceptowało porządek (standardy) ustalony odgórnie, poddawało się komunikacji jednokierunkowej, nie zadawało pytań. Uwypuklenie kultur mniejszościowych różnicowałoby społeczeństwo, generowało pytania, wymuszało komunikację dwustronną, czyli neutralizowało nowomowę, osłabiało autorytet władzy. Dlatego poza asymilacją popierano emigrację, która potwierdzała obcość mniejszości, stąd masowe wyjazdy Polaków do Niemiec w latach 70-tych, przymusowy exodus w roku 1968.

Dzieje dyskryminacji mniejszości narodowych w Polsce obejmują kilka etapów. W połowie lat 50. doszło do masowej migracji ekonomicznej ludności, co sprzyjało procesom asymilacyjnym. Społeczeństwo dominujące przejmowało jednostki odrywające się od swoich grup mniejszościowych, stąd reakcje konsolidacyjne po drugiej stronie, których konsekwencją było powstawanie zamkniętych wspólnot mniejszościowych o charakterze getta. Jednocześnie narastające represje stalinowskie skutkowały ukrywaniem przynależności etnicznej i narodowościowej, uniemożliwiały jej manifestowanie, wiedza w tym zakresie była ograniczona społecznie. W okresie odwilży poszukiwano winnego wcześniejszego terroru, winny był obcy/inny, dlatego zaostrzono kontrolę nad mniejszościami i zaczęto ścigać je za nielojalność. PZPR oficjalnie opowiadała się przeciwko dyskryminacji narodowościowej, jednak w praktyce towarzystwom mniejszościowym nakazano, tak jak wszystkim obywatelom i stowarzyszeniom, realizować we własnym środowisku politykę partii, co miało przyśpieszyć procesy asymilacyjne. Mniejszości mogły jedynie istnieć i oficjalnie działać w obrębie określonych norm ideologicznych i w określonych z góry formach. Ich działalność miała koncentrować się na działalności folklorystycznej i artystycznej. Państwo finansowało zespoły śpiewacze i teatralne, ale jednocześnie ograniczało szkolnictwo mniejszościowe. Kulminacją tych działań był rok 1968, który spowodował, że Polacy już nie tylko nie manifestowali swojej odmienności, zaczęli ją ukrywać, wiedza o tożsamości etnicznej przestała być ograniczana, stała się tajna. Uchwała II Plenum PZPR z 1976 roku "O moralno-politycznej jedności narodu polskiego" wzmocniła tezę „o jednolitym charakterze państwa polskiego", której towarzyszyły dalsze działania dyskryminacyjne.

Konsekwencją takiej polityki były odziedziczone po PRL-u utajnione lub jawne konflikty etniczne. Powszechny brak wiedzy na temat kultur mniejszościowych 
w Polsce skutkował wzmocnieniem negatywnych stereotypów etnicznych, co powodowało, że niechętnie przyznawano się do bycia obcym/innym. Wcześniejsza polityka jednorodnego państwa znalazła swoje odzwierciedlenie w programach szkolnych. Młodzież o żyjących w Polsce mniejszościach dowiadywała się na lekcjach historii, jako obrazie przeszłości. Nie informowano o wpływie grup mniejszościowych na rozwój polskiej nauki i kultury. Takich informacji nie przekazywano także na innych lekcjach, choćby języka polskiego, wychowania muzycznego, wychowania plastycznego. O współczesnym statusie mniejszości podręczniki szkolne nie informowały. System szkolnictwa w państwie totalitarnym nie przewidywał nauki komunikacji interkulturowej, nie uwzględniał relatywizmu kulturowego, różnych perspektyw i punktów widzenia. Jakakolwiek różnorodność nie służyła państwu, dlatego nie mogła znaleźć swojego odzwierciedlenia w systemie edukacji. Polacy uwierzyli lub pogodzili się z tezą, że są narodem monokulturowym, że odmienność kultur, ideologii w tym religii zagraża stabilności ich kraju. Będąc grupą dominującą odziedziczyli posttotalitarny strach przed innością, który obecny jest $\mathrm{w}$ ich pamięci społecznej.

\section{Od integracji do multikulturalizmu - relacje interkulturowe $\mathrm{w}$ Polsce po 1989 roku}

Katolicko-narodowy charakter zrywu solidarnościowego nie skutkował modyfikacją postaw Polaków wobec mniejszości oraz ich sytuacji społecznej, dopiero przełom 1989 roku zmienił sytuację prawną i oficjalną ${ }^{8}$ mniejszości narodowych i etnicznych w Polsce. Ustawa z dnia 7 września 1991 r. o systemie oświaty, wprowadziła wymóg podtrzymania tożsamości narodowej, etnicznej, językowej i religijnej, a w szczególności naukę języka oraz własnej historii i kultury w szkołach publicznych (Dziennik Ustaw 1991, nr 95, poz. 425). Ustawa z dnia 29 grudnia 1992 r. o radiofonii i telewizji nakazywała publicznemu radiu i publicznej telewizji uwzględnić potrzeby mniejszości narodowych i etnicznych (Dziennik Ustaw 1992, nr 7, poz. 34). Konstytucja Rzeczypospolitej Polskiej z 1997 roku podkreśliła konieczność ochrony praw mniejszości narodowych. Podmiotem i źródłem władzy suwerennej stał się naród - zbiorowość ale w sensie politycznym a nie etnicznym. Narodem stali się wszyscy ci, którzy posiadali obywatelstwo polskie oraz ci, którzy posiadali takie obywatelstwo po 11 listopada 1918. Obok pojęcia naród pojawiło się pojęcie społeczeństwo obywatelskie, które uzyskało wpływ na kierunek polityki państwa poprzez mające różnorakie cele grupy interesu, także wspólnoty mniejszościowe. Konstytucja ta zapewniła wszystkim obywatelom, należącym do mniejszości narodowych i etnicznych, wolność zachowania i rozwoju własnego

\footnotetext{
${ }^{8}$ Zmieniła się sytuacja prawna i oficjalna, relacje nieoficjalne nadal wymagają monitorowania.
} 
języka, zachowania obyczajów i tradycji oraz rozwoju własnej kultury, umożliwiła im tworzenie własnych instytucji edukacyjnych, kulturalnych, instytucji służących ochronie tożsamości religijnej. Dała także prawo do nieskrępowanego wykonywania praktyk religijnych, gwarantowała wolność sumienia i wyznania, wprowadzała zakaz dyskryminacji bądź uprzywilejowania z powodu religii. Konstytucja ta dała także prawo do swobodnego posługiwania się językiem mniejszości w życiu prywatnym i publicznie. Rzeczpospolita Polska, jako kraj demokratyczny, przyznała mniejszościom swobodny dostęp do dóbr kultury, do służb publicznych, wykształcenia i świadczeń zdrowotnych, a także zapewniła prawa wyborcze oraz prawa do swobodnego zrzeszania się..$^{9}$ Ustawa z dnia 6 czerwca 1997 o Kodeksie karnym (Waglowski) przewiduje karanie przestępstw popełnianych na tle etnicznym, natomiast Ustawa o ochronie danych osobowych (Waglowski) zabrania przetwarzania danych ujawniających pochodzenie etniczne. Osobowość prawną mniejszości narodowych i etnicznych w Polsce określiła Ustawa z 6 stycznia 2005 (Dziennik Ustaw 2005, nr 17, poz. 141, nr 62, poz. 550); (Dziennik Ustaw 2009, nr 31, poz. 206, nr 157, poz. 1241).

Mniejszości w Polsce poza konstytucyjnym zabezpieczeniem prawnym, mają gwarantowaną ochronę międzynarodowymi aktami prawnymi. Jako członek ONZ, Polska musi respektować postanowienia Międzynarodowego Paktu Praw Obywatelskich i Politycznych z 1966 r. oraz Deklaracji Praw Osób Należących do Mniejszości Narodowych lub Etnicznych, Religijnych i Językowych, które zakazują dyskryminacji jednostek ze względu na rasę, religię, płeć, poglądy polityczne, pochodzenie społeczne i narodowość. W 1995 Polska podpisała Europejską Konwencję Ramową o Ochronie Mniejszości Narodowych z inicjatywy Rady Europy, która gwarantuje, że każdy członek mniejszości narodowej ma prawo do swobodnego określania swojej narodowości poprzez naukę języka ojczystego i w tymże języku oraz do swobodnego używania go w życiu prywatnym i publicznym.

Procesy asymilacyjne wzmacniające totalitaryzm zostały zastąpione rozwiązaniami prawnymi dążącymi do integracji grup mniejszościowych z grupą dominującą. Integracja jako forma relacji na granicy grup kulturowych $w$ ramach jednego państwa budzi wiele wątpliwości. Interesujące z punktu widzenia antropologii komunikacji jest wskazanie przez Todda Endelmana integracji jako jednego z elementów asymilacji. Według niego wynikiem integracji jest otwarcie się grup mniejszościowych na społeczeństwo dominujące. Jednak Endelman dostrzega jego wyłącznie jednokierunkowy charakter, dlatego łączy ten proces $\mathrm{z}$ akulturacją i asymilacją (Endelman 81). Przejście od totalitaryzmu do demokracji zmodyfikowało przepływ informacji, komunikacja interpersonalna ma obecnie dwukierun-

\footnotetext{
${ }^{9}$ Konstytucja Rzeczypospolitej Polskiej z dnia 2 kwietnia 1997 r. uchwalona przez Zgromadzenie Narodowe, przyjęta przez Naród w referendum konstytucyjnym w dniu 25 maja 1997 r., podpisana przez Prezydenta Rzeczypospolitej Polskiej w dniu 16 lipca 1997.
} 
kowy charakter, dotyczy to także relacji między społeczeństwem dominującym i mniejszościowym

Na możliwości takiego partnerskiego porozumienia w ramach integracji zwrócił uwagę Anthony Giddens (Giddens). Wskazany przez niego model relacji proponuje zastąpienie jednokierunkowej asymilacji dwukierunkową integracją. Integrację postrzega on jako sposób zorganizowania różnorodnych elementów, tworzących społeczeństwo. Porządek ten odwołuje się do konwencji kulturowej i systemu aksjologicznego, obejmuje relacje między jednostkami i grupami społecznymi (Piekut).

W przypadku integracji relacje między społeczeństwem dominującym a mniejszością powinny być wynikiem procesu włączania odmiennych kulturowo elementów do istniejących systemów społecznych w taki sposób, by nie naruszały one harmonijnego i skutecznego funkcjonowania tych systemów i nie eliminowały ich elementów tożsamościowych. Fortunna integracja jest procesem złożonym, dwukierunkowym, długotrwałym, wielopłaszczyznowym. Podstawowe komponenty integracji to:

- komponent strukturalny, czyli nabycie podstawowych praw oraz uzyskanie dostępu dla członków mniejszości etnicznych do wszystkich społecznych rozwiązań strukturalnych;

- komponent kulturowy, czyli proces wymiany kulturowej, z zachowaniem świadomości różnorodności;

- komponent społeczny, czyli osobiste relacje społeczne nawiązywane przez członków mniejszości etnicznych i społeczeństwa dominującego oraz przynależność do formalnych i nieformalnych interwspólnotowych etnicznie i narodowo grup społecznych;

- komponent identyfikacyjny, czyli poczucie szerszej otwartej wspólnotowości ze społeczeństwem dominującym, bez utraty własnej wspólnotowej tożsamości kulturowej.

Najczęściej wymienianymi sygnałami udanej integracji wspólnot odmiennych kulturowo są:

- osiągnięcie przez jej członków odpowiedniej kompetencji językowej,

- uzyskanie zatrudnienia w zawodach, odpowiadających kwalifikacjom członków wspólnoty odmiennej etnicznie,

- uzyskanie przez nich odpowiedniego statusu ekonomicznego,

- ich udział w życiu politycznym,

- brak konfliktów z prawem.

Brak wśród zebranych sygnałów, uwarunkowań, które powinny kształtować społeczeństwo zróżnicowane kulturowo:

- trwałego poczucia własnej odrębności kulturowej,

- umiejętnego funkcjonowanie na granicy kultur. 
Z perspektywy komunikologicznej bez tych dwu ostatnich wskazań nie można procesu integracyjnego nazwać fortunnym, gdyż nie zakłada on ochrony tożsamości i w jego konsekwencji nie powstaje otwarta wspólnota państwowa, składająca się ze wspólnot odmiennych kulturowo, powiązanych różnymi relacjami państwotwórczymi.

Potwierdza to fakt, że entuzjaści tej formy relacji interwspólnotowych za zintegrowany, uważają taki system społeczny, w którym cele wyznaczane przez wybraną kulturę są w pełni akceptowane przez wszystkie jednostki i osiągane za pomocą społecznie akceptowanych środków. Gdy określenie wybrana kultura dotyczy kultury dominującej, oznacza to, że mamy do czynienia z zakończonym procesem asymilacyjnym, nie integracyjnym. Dlatego celem obecnych rozwiązań prawnych w Polsce powinno być wprowadzanie relacji wielokulturowych.

Multikulturalizm wypracował własne wzorce zarządzania relacjami międzykulturowymi. Relacje te oparte są na poszanowaniu wszelkich różnic w kulturze, pochodzeniu, religii czy obyczajach, pozwalają tworzyć otwarte wspólnoty państwowe, w ramach których współistnieją obok siebie odmienne kulturowo równoprawne wspólnoty narodowe (Stefańska). Tak funkcjonują wielojęzyczne kraje: Szwajcaria, Belgia, Kanada. Tak próbuje budować swoje wewnętrzne relacje Unia Europejska. Współcześnie multikulturalizm jest powszechnie akceptowanym rozwiązaniem społeczno-politycznym, stosowanym w krajach, zamieszkiwanych przez różne etnicznie grupy ludności. Idea społeczeństwa multikulturowego wykształciła się w miarę nasilania się ruchów migracyjnych, napływu do Europy przedstawicieli odmiennych kultur, religii i ich stałego zamieszkania $\mathrm{w}$ krajach wysokorozwiniętych, takich jak Niemcy, Francja, Wielka Brytania. Zwolennicy multikulturalizmu uważają, że członkowie grup mniejszościowych powinni zachować swoją odrębność językową, kulturową oraz relacji społecznych, gdyż nie zagraża to żadnej innej tożsamości narodowej. Tożsamość własnej odrębności kulturowej pogłębia, według nich, tolerancję dla odmiennych stylów życia. Polityka multikulturalizmu nie tylko przyznaje członkom mniejszości równe prawa bez wymogu wyrzeczenia się innych afiliacji kulturowych, daje im także prawa szczególne, uwarunkowane etnicznie.

Rozwiązania prawne wprowadzone w Polsce po 1989 roku, poprzez prawa szczególne dla mniejszości, dały początek multikulturalizmowi, jednak w niewielkim stopniu wpłynęły na zmianę postaw społecznych współczesnych Polaków wobec mniejszości. Oznacza to, że uzasadnione i wystarczające rozwiązania prawne nie znalazły swego odzwierciedlenia w relacjach nieoficjalnych, zarówno prywatnych jak i publicznych. Sprzeciw wobec państwa, nieakceptowanie stanowionych norm prawnych, oczekiwanie standardowych rozwiązań dla komunikacji interpersonalnej, utożsamianie równości wobec prawa z brakiem różnorodności kulturowej, w konsekwencji odrzucenie relatywizmu kulturowego, to sygnały, że posttotalitarna pamięć społeczna, pomimo przekształceń prawnych, jest ciągle 
żywa. Wielu Polakom trudno pogodzić się, że Polska nie jest monokulturowa, że Polacy różnią się, że mają odmienne systemy wartości, utrwalone $\mathrm{w}$ ich pierwszych językach, kształtowane przez wieki, także poprzez typ kontaktów międzykulturowych. Stąd często $\mathrm{w}$ dyskusji społecznej pojawiają się użycia językowe: prawdziwy Polak, prawdziwy patriota, uniwersalny system wartości, które uruchamiają specyficzny sposób kategoryzacji swój/obcy.

Wolność słowa, która pozwala głośno podawać w wątpliwość obowiązujące rozwiązania prawne, upowszechniane zasady społeczne i etyczne, deprecjonować relatywizm kulturowy, stała się dla Polaków narzędziem obrony dotychczasowej postkomunistycznej świadomości, stanowiącej fundament tożsamości narodowej. Mit, że wszyscy Polacy byli i są tolerancyjni, zawsze stają w obronie uciskanych, że nigdy nie dokonywali zbrodni na tle rasistowskim, nie uczestniczyli w eksterminacji Żydów, nie dyskryminowali Romów kształtuje poczucie bezpieczeństwa, jest jednocześnie przejawem postkomunistycznego konformizmu i oportunizmu. Falsyfikowanie tego mitu wywołuje gwałtowną reakcję obronną, w konsekwencji nasilają się postawy społeczne, nieakceptujące odmienności etnicznej. Na relacje między grupami dominującą i mniejszościową wpływ mają także jednostronne działania administracyjne. Państwo koncentruje się na ochronie mniejszości, programy realizowane przez organizacje pozarządowe i sam rząd dotyczą bezpośrednio wspólnot mniejszościowych odmiennych kulturowo, grupa dominująca odbiera to jako formę wykluczania lub jako potwierdzenie własnej wyższości/dominacji. Brak powszechnej wiedzy na temat mniejszości jest przyczyną strachu, który rodzi agresję i stanowi źródło negatywnych stereotypów. To, co nieznane, przeraża i budzi sprzeciw, dlatego działania mające na celu budowanie właściwych relacji społecznych powinny być kierowane również do członków wspólnoty dominującej.

Szkolne programy minimum, choć już wielokrotnie modernizowane, nadal nie przekazują wiedzy na temat kultur mniejszościowych obecnych w Polsce, nie informują o ich wpływie na rozwój kultury dominującej, nie przygotowują też do komunikacji interkulturowej. Takie pojęcia jak perspektywa, punkt widzenia, relatywizm są nadal obce współczesnym polskim absolwentom szkół średnich. Lekcje historii to opis kolejnych konfliktów zbrojnych i porażek lub sukcesów militarnych, rzadziej osiągnięć naukowych, zdobyczy kulturalnych. Stąd reprezentantów mniejszości narodowych młodzi absolwenci szkół kategoryzują: ten co walczył $z$ nami $i$ ten co walczyt przeciw nam. Polska szkoła formuje postawy narodowe i kształci przyszłych obywateli państwa narodowego, monokulturowego. Przyczyniają się do tego także mniejszości narodowe, które po działaniach asymilacyjnych państwa totalitarnego bardzo wolno przekształcają się we wspólnoty otwarte, ukierunkowane na komunikację nie tylko wewnątrzwspólnotową, ale także zewnętrzną. Badania nad komunikacją interkulturową potwierdziły, że najczęstszymi barierami, utrudniającymi komunikację na granicy kultur są: 
- brak powszechnej wiedzy na temat kultur mniejszości,

- nieznajomość języków mniejszości i jego wytworów,

- narodowy/monokulturowy charakter edukacji polskiej,

- brak motywacji do poszerzania wiedzy na temat mniejszości,

- poczucie winy z powodu Holocaustu, dyskryminacji.

Wymienione wyżej bariery opóźniają wprowadzanie rozwiązań integracyjnych i wielokulturowych, sprawiają, że Polska w relacjach nieoficjalnych nadal postrzegana jest jako państwo monokulturowe, ukierunkowane na wzmacnianie grupy dominującej oraz utrwalanie mitu ugruntowującego ograniczoną tożsamość narodową.

\section{Polskie postawy społeczne wobec Innego}

Odejście od państwa narodowego w kierunku integracji i multikulturalizmu wymaga przede wszystkim modyfikacji postaw społecznych przyjmowanych przez obywateli wobec wyraźnej inności części ich współobywateli w zróżnicowanych sytuacjach komunikacyjnych, także nieoficjalnych. Najbardziej dezintegrującą postawą społeczną jest zachowanie, przez niektórych akceptowane jako nieagresywne, polegające na biernym odrzuceniu wszystkiego, co jest inne. Polega ono na niedostrzeganiu różnic, nieinteresowaniu się innymi - obcymi, założeniu, że we własnej przestrzeni oni nie istnieją. Taki alienacyjny stosunek do odmiennych kulturowo członków wspólnoty nie służy budowaniu pogłębionych więzi, zagraża stabilności społecznej i w przypadku zbyt silnej afiliacji odmienności przez mniejszość może doprowadzić do niekontrolowanych zachowań agresywnych.

Wielu uczniów w polskich szkołach udaje przed sobą i innymi, że wszyscy ich koledzy w klasie są tacy sami, nie stawia ich to przed koniecznością przyjęcia określonej postawy społecznej wobec inności. Badania prowadzone przeze mnie w klasach polsko-romskich pokazały, że nawet przy wyraźnie odmiennych znakach kulturowych (strój, język) nauczyciele i uczniowie przyjmowali, że nie ma między nimi różnic, tak było łatwiej. W konsekwencji nie realizowano szczególnych potrzeb społeczno-edukacyjnych, wynikających z odmienności kulturowej grupy mniejszościowej (Grzelak, Grzelak-Piaskowska). Podobny wzór zachowania narzuca tabu społeczne, dotyczące dyskursu religijnego i etnicznego. Z osobami o odmiennym wyznaniu młodzi Polacy nie prowadzą dyskusji światopoglądowych, uczniowie stwierdzali $\mathrm{w}$ wywiadach i ankietach: lepiej na ten temat nie rozmawiać, bo można kogoś urazić (brak wiedzy); religia jest intymna sprawa każdego; znam swoja religię, po co rozmawiać o innych wyznaniach; religia jest po to, by wierzyć, a nie dyskutować. Tabu językowe ogranicza także dyskusję na temat przynależności etnicznej lub narodowej. Poszukiwanie tych informacji jest według uczniów nie- 
grzeczne: nie pytam z jakiego kraju jest tata Adama (chłopiec jest czarnoskóry), bo po co podkreślać, że jest Murzynem; oni jedza na przerwach coś dziwnego, ale nie pytamy dlaczego i co, bo to nie nasza sprawa (o koleżankach, których mama pochodzi z Indii); one w ogóle nie chodza w spodniach, nie pytatyśmy się dlaczego, musi im być okropnie niewygodnie (o Romkach) ${ }^{10}$. Tabuizacja tożsamości kulturowej innych/obcych skutkuje zamknięciem grupy mniejszościowej, generuje jej izolację. Taka postawa sygnalizująca wycofanie się, nie jest negowana, gdyż jest trudna do zauważenia, bierność nie wymaga samookreślenia werbalnego i niewerbalnego, nie wysyła sygnałów, które wymagają oceny. W jednej z dyskusji medialnych na temat odbioru filmu "Pokłosie” pojawiła się teza, że brak tekstów kultury na temat różnorodnych relacji polsko-żydowskich oraz brak bohaterów pochodzenia żydowskiego we współczesnej twórczości artystycznej nie musi odzwierciedlać braku kontaktów lub braku wiedzy, może także być sygnałem antysemityzmu. Stwierdzenie to potwierdza fakt, że równie rzadko obecne $\mathrm{w}$ naszych manifestacjach kulturowych (tekstach kultury) są także inne mniejszości etniczne i narodowe, jeśli już się pojawiają to $\mathrm{w}$ wyizolowanych realizacjach.

Łatwiej neutralizować zachowania wynikające z nietolerancji, które posiadają określone identyfikatory werbalne i niewerbalne. Wyrażenie poglądu pozwala podjąć dyskusję, wykorzystując argumentację i dowodzenie naukowe, a także perswazję emocjonalną, można przeciwstawić się takiej postawie. Zdefiniowanie swoich poglądów otwiera możliwości budowania niełatwych, ale jednak relacji. Przemyślany, obudowany rozumną interakcją dyskurs obniża poziom agresji i niechęci. Prowadzone przeze mnie badania wśród licealistów potwierdzają, że najczęstszym źródłem braku tolerancji jest strach przed nieznaną innością, operowanie negatywnymi stereotypami, czyli niewiedza lub wiedza płytka, niezweryfikowana i niepogłębiona na temat danej kultury. Każda próba poszerzenia tej wiedzy generuje pytania, inicjuje dyskusję, otwiera na inność, motywuje do modyfikacji postawy, skutkuje chęcią poznania.

Powszechne jest przekonanie, że postawa oparta na tolerancji wystarcza, by zbudować poprawne relacje na granicy kultur. Prowadzone przeze mnie badania pokazały jednak, że często tolerancji towarzyszy brak akceptacji, który może $\mathrm{w}$ niektórych sytuacjach zaowocować zachowaniami agresywnymi. Pozwala się innym być innymi, wymagając tylko, by nie epatowali odmiennością, by jej nie afiliowali. Toleruje się ich obecność, daje im te same prawa, nawet akceptuje prawa specjalne, warunkowane kulturą. Nie towarzyszy jednak tej postawie zainteresowanie odmiennością, osoby tolerancyjne nie wykazują aktywności w celu pozytywnego poznania tych, których tolerują. To w znacznym stopniu ogranicza

${ }^{10}$ Cytaty pochodzą z dyskusji, prowadzonych w czasie zajęć w Instytucie Kultury Europejskiej UAM, przewidzianych programem Klasy akademickiej, w roku szkolnym 2013/2014. 
relacje, koncentruje je na problemach bytowych ${ }^{11}$. Przejawem takiej postawy są jednokierunkowe rozwiązania prawne i działania interkulturowe w Polsce.

W społeczeństwie multikulturowym najfortunniejszą postawą jest postawa oparta na akceptacji. Postawę tę cechuje nie tylko tolerancja dla inności, ale także zadowolenie z jej istnienia, wzmocnione zainteresowaniem, chęcią poznania. Taki stosunek do inności umożliwia budowanie pogłębionych relacji, opartych na wymianie informacji kulturowych, a to kształtuje dwukierunkowość tychże relacji. Zdobywana w ten sposób wiedza jest czynnikiem spajającym wspólnoty wielokulturowe.

\section{Podsumowanie}

Teza, że tylko w wyniku asymilacji członkowie mniejszości etnicznych staną się pełnoprawnymi obywatelami danego kraju, sfalsyfikowała się. Proces ten ze względu na swój jednokierunkowy charakter - członkowie mniejszości etnicznych przejmują język, normy oraz zachowania społeczeństwa dominującego, bez analogicznego dostosowania ze strony tegoż społeczeństwa - narusza zasady równości wobec prawa wszystkich obywateli danego państwa.

Polityka integracyjna, która w przeciwieństwie do asymilacji, zakładała, że proces wzajemnego dostosowania się mniejszości etnicznej i społeczeństwa dominującego ma charakter dwustronny - obie grupy nie tylko akceptują wspólną kulturę, także wnoszą do niej własny wkład - choć sprawiedliwa społecznie, pogłębia jednak procesy interferencyjne i zaciera odrębności kulturowe, w wyniku czego może skutkować utratą tożsamości kulturowej zarówno członków mniejszości etnicznych jak i społeczeństwa dominującego.

Idea multikulturowości także nie jest doskonała. Założenie, że ludzie pochodzący z różnych grup etnicznych uczą się od siebie odmiennych kultur, jednocześnie zachowując poczucie kulturowej różnorodności oraz świadomość swojego kulturowego dziedzictwa, nie jest założeniem państwotwórczym, uderza w mniejszości etniczne, gdyż skutkuje ograniczeniem ich dostępu do dóbr ekonomicznych, społecznych i edukacyjnych, wypracowanych przez państwo.

Mając na uwadze podstawowe problemy, utrudniające komunikację interkulturową $w$ Polsce, które skutkują pogłębianiem się stereotypizacji relacji na granicy kultur, proponuję koncepcję, która pozwala przyjąc system prawno-społeczny łączący wymienione wyżej rozwiązania.

\footnotetext{
$11 \mathrm{~W}$ trakcie wywiadu często spotykałam się ze stwierdzeniem uczniów na temat wyznawców islamu: Niech oni osiedlają się $u$ nas, ale meczet niech budują $w$ Poznaniu, $w$ tym dużym mieście nie będzie on zwracat uwagi. Takich wypowiedzi brak w kontekście świątyń żydowskich, jednak wynika to tylko z poprawności politycznej.
} 
Procesy asymilacyjne powinny dotyczyć niezbędnego minimum, które usprawni funkcjonowanie grup odmiennych etnicznie w społeczeństwie dominującym. Procesy integracyjne mogą pomóc we wzajemnej edukacji na temat odrębności kulturowych, pozwolą wypracować techniki komunikacyjne na granicy kultur oraz wyeliminują kategorię swój/obcy, rozumianą jako opozycję przyjaciel/wróg. Włączą także grupy mniejszościowe $\mathrm{w}$ procesy kulturotwórcze społeczeństwa mieszanego etnicznie. Multikulturowość jest natomiast niezbędna w utrwalaniu odrębności etnicznej grup, tworzących społeczeństwa wielokulturowe. Ograniczy ona $\mathrm{w}$ ramach komunikacji międzykulturowej przebiegające zbyt dynamicznie procesy interferencyjne, które mogą wywołać poczucie zagrożenia i sprowokować działania dezintegracyjne. Wielokulturowość nie może być jednak rozumiana jako mieszanka zróżnicowanych etnicznie znaków bez możliwości ich identyfikacji tożsamościowej, dlatego społeczeństwa wielokulturowe powinny dostrzegać swoje różnice etniczne, znać ich genezę, umieć interpretować semiotycznie swoje przekazy. Obowiązek edukacji $\mathrm{w}$ tym zakresie spoczywa na państwie, dlatego modułowe programy szkolne powinny uwzględniać zróżnicowanie kulturowe uczniów ${ }^{12}$. Właściwa edukacja zmodyfikuje pojęcie wspólnoty narodowej, podkreśli jej różnorodność kulturową jako wartość dodaną, pozwoli zneutralizować zachowania warunkowane pamięcią posttotalitarną identyfikującą obywateli jednorodnego kulturowo państwa narodowego.

Wielokulturowość, wzmocniona ograniczonymi działaniami asymilacyjno-integracyjnymi, obudowana wiedzą kulturową stanowi fundament dla relacji interpersonalnych w społeczeństwach zróżnicowanych kulturowo.

\section{BIBLIOGRAFIA}

Endelman, Todd. „Assimilation”. The YIVO Encyklopedia of Jews in Eastern Europe. Red. Gershon Hundert. New Haven-London: Yale University Press, 2008.

Fromm, Erich. Ucieczka od wolności. Przeł. Andrzej i Olga Zimilscy. Warszawa: Wydawnictwo Czytelnik, 2008.

Funkenstein, Amos. „The Dialectics of Assimilation”. Jewish Social Studies (1995) 1/2. S. 1-14.

Giddens, Anthony. Socjologia. Przeł. Olga Siara, Alina Szulżycka, Paweł Tomanek. Warszawa: Wydawnictwo Naukowe PWN, 2004.

Grzelak Eliza, Grzelak-Piaskowska Joanna. „Intercultural communications. Roma-Polish relationships In school environment - early educations stage". Studia Europea Gnesnensia 7 (2013). S. 113-140.

$12 \mathrm{~W}$ ramach projektu „Edukacja dla integracji” - program podniesienia poziomu ksztatcenia językowego dzieci i młodzieży romskiej finansowanego ze środków Unii Europejskiej z Europejskiego Funduszu Społecznego (PO KL 01.03.01-00-179/09) zaproponowałam modułowe rozwiązania edukacyjne dla klas polsko-romskich, które po modyfikacji, uzasadnionej relatywizmem językowym, mogą zostać zaadoptowane do nauczania we wszystkich klasach, nie tylko tych zróżnicowanych kulturowo. Zob. (Grzelak, Grzelak-Piaskowska). 
Grzelak, Eliza. „Między wolnością a zniewoleniem, czyli w jaki sposób rozwój technologiczny determinuje komunikację międzyludzką". Przeobrażenia w języku i komunikacji medialnej na przełomie XX i XXI wieku. Red. Małgorzata Karwatowska, Adam Siwiec. Chełm: Państwowa Wyższa Szkoła Zawodowa w Chełmie, 2010. S. 261-273.

Grzelak, Eliza. „Nauczanie języka polskiego Romów - perspektywa etnolingwistyczna”. Dyskursy trzeciego tysiaclecia. Red. Ewa Pajewska. Szczecin: Instytut Polonistyki i Kulturoznawstwa, 2011. S. $47-67$.

Grzelakowa Eliza, Rzeszutko Małgorzata. „Relatywizm kulturowy wobec językowej kreacji świata w mediach". Moda jako problem lingwistyczny. Red. Krystyna Wojtczuk. Siedlce: Wydawnictwo Akademii Podlaskiej, 2002.

Grzelakowa, Eliza. „Zdarzenia komunikacyjne służące budowaniu więzi społecznej”. Oblicza komunikacji. T. 1. Język a komunikacja. Red. Irena Kamińska-Szmaj, Tomasz Piekut, Monika Zaśko-Zielińska. Kraków: Krakowskie Towarzystwo Popularyzowania Wiedzy o Komunikacji Językowej tErtium, 2006.

Kapica, Tomasz. „Moda na klasy mundurowe kwitnie”. 2013. Web. 31.07.2014. <http://www.nto.pl/ apps/pbcs.dll/article?AID=/20130829/REGION/130829573>

Kłoskowska, Antonina. Kultury narodowe u korzeni. Warszawa: Wydawnictwo Naukowe PWN, 2005.

Krótki stownik filozoficzny. Red. Mark Moiseevič Rozental, Pavel Fedorovič Judin. Warszawa: „Książka i Wiedza", 1955. S. 246-248.

Piekut, Aneta. „Wielość wymiarów - zatem jaka integracja? Przegląd tematyki i badań integracyjnych". Problemy integracji imigrantów. Red. Sławomir Łodziński, Aleksandra Grzymała-Kozłowska. Warszawa: Wydawnictwa Uniwersytetu Warszawskiego, 2009. S. 218-228.

Schaff, Adam. Jezzk a poznanie. Warszawa: Państwowe Wydawnictwo Naukowe, 1967.

Stefańska, Roma. „Między multikulturalizmem a asymilacją. Polityki integracyjne w Europie”. Problemy integracji imigrantów. Red. Sławomir Łodziński, Aleksandra Grzymała-Kozłowska. Warszawa: Wydawnictwa Uniwersytetu Warszawskiego, 2009. S. 123-156.

Tischner, Józef. Etyka solidarności oraz Homo sovieticus. Kraków: Znak, 1992.

Tischner, Józef. Nieszczęsny dar wolności. Kraków: Znak, 1993.

Turowicz, Jerzy. „Pamięć i rodowód”. Tygodnik Powszechny (1993) 45.

Waglowski, Piotr. „Ochrona dóbr osobistych i danych osobowych”. 2009. Web. 31.07.2014. <www.web. gov.pl/g2/big/2009>

Wdowiak, Paweł. „Homo postsovieticus lub Homo sovieticus po latach”. Web. 31.07.2014. <www.racjo nalista.pl/kk.php/s.5100>

\section{Akty prawne}

Konstytucja Polskiej Rzeczypospolitej Ludowej uchwalona przez Sejm Ustawodawczy w dniu 22 lipca $1952 \mathrm{r}$.

Ustawa z dnia 7.września 1991 o systemie oświaty.

Ustawa z dnia 29 grudnia 1992 o radiofonii i telewizji.

Ustawa z dnia 6 stycznia 2005 r. o mniejszościach narodowych i etnicznych oraz o języku regionalnym.

Ustawa z dnia 7 października 1999 o języku polskim.

Ustawa z 29 sierpnia 1997 o ochronie danych osobowych.

Ustawa z dnia 26 stycznia 1984. Prawo prasowe (nowelizacja 19.07.2013) 